\title{
Physical-mechanical potential properties of wastes from glass lapping to produce mortar as partial replacement of the conventional aggregate
}

\section{Propriedades físico-mecânicas de resíduos da lapidação de vidro utilizados em argamassa cimentícia como substituinte parcial do agregado convencional}
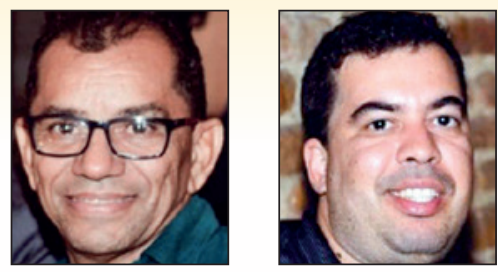

U. G. RIBEIRO

prof.umberto.ribeiro@gmail.com https://orcid.org/0000-0001-9444-745X

D. F. SANTOS

dirceufernandes@live.ca https://orcid.org/0000-0001-8403-2701

\begin{abstract}
Glass lapping residues (RLV) are fine tailings from the processing of glass for civil construction, commonly non-recyclable. The present study analyzed the use of these residues in Portland cement mortar composition, partially replacing the conventional aggregate, aiming at better compaction. Percentages of residues were adopted at $0 \%$ (reference), $5 \%, 10 \%$ and $20 \%$ by mass, replacing the fine conventional aggregate (sand). The binder used was Portland cement CP IV-32. The RLV and fine aggregate were submitted to physical tests, through grain size analysis, grain shape and specific mass; RLV and cement, in turn, submitted to chemical analysis by X-ray spectrometry, to identify the compounds. To evaluate the compressive strength and compaction analysis of the composite in the hardened state, cylindrical specimens 50x100 mm were produced. ANOVA (Analisys of Variance) and Coefficient of Variation showed that the RLV added in 5\% resulted in lower voids indexes and moisture absorption than the conventional one. The tests also showed best mechanical performance on compression analisys ( $30,2 \mathrm{MPa})$ for $5 \%$ of residues in the composite, surpassing the conventional one.
\end{abstract}

Keywords: compaction of mortars, alternative materials, glass lapping wastes, recycling.

\section{Resumo}

Resíduos da lapidação de vidros (RLV) são rejeitos finos do beneficiamento de vidros para construção civil, comumente descartados e não recicláveis. O presente estudo analisou a utilização destes resíduos na composição de argamassa de cimento Portland, substituindo parcialmente o agregado convencional, visando uma melhor compactação. Adotaram-se percentuais de resíduos em 0\% (referência), $5 \%, 10 \%$ e $20 \%$ em massa, substituindo o agregado miúdo (areia). O aglomerante utilizado foi o cimento Portland CP IV-32. O RLV e agregado miúdo foram submetidos a ensaios físicos, através de análise granulométrica, forma dos grãos e massa específica; RLV e cimento, por sua vez, submetidos à análise química por espectrometria de raios-X, para identificação dos compostos. Para avaliação da resistência à compressão e análise da compactação do compósito em estado endurecido, foram confeccionados corpos de prova cilíndricos 50x100 mm. ANOVA (Analisys of Variance) e Coeficiente de Variação mostraram que o RLV adicionado em 5\% resultou menores índices de vazios e absorção de umidade do que o convencional. Os testes também mostraram que $5 \%$ do resíduo no compósito apresenta o melhor desempenho mecânico por compressão (30,2 MPa), superando o convencional.

Palavras-chave: compactação de argamassas, materiais alternativos, resíduos de lapidação de vidro, reciclagem.

Faculdade de Rondônia, Coordenação de Pesquisa e Extensão, Porto Velho,RO, Brasil. 


\section{Introduction}

Brazilian law encourages the adoption of solid waste disposal practices aimed at environmental non-degradation, encouraging non-generation and recommends reuse, avoiding inappropriate final disposal [1].

The processing (production) of glass to civil construction, in this context, basically generates two types of waste: the "shards" or large chips (which can be recycled by the glass industry in the form of household utensils, packaging, etc.) and a fine powder, result of the cutting, drilling and finishing of the glass board, which are rejected in the recyclers because they damage the ovens, due its fineness [2]. The reuse of fine waste can offer advantages such as cost reduction, no negative environmental impact and no natural resource consumption [3], indirect objectives in this work.

In the State of Rondônia, Brazil, fine waste is generated by three glass processing industries today. In Porto Velho, located to the north of the State, information was collected at a local industry about the production, processing of glass and generation of fine waste. According to the information obtained from the Company's technical staff, glass lapping waste (RLV) is a waste from cutting and cutting machines, which thin and finish the sides of the boards and the perforation of the glass. According to the Company, approximately 800 $\mathrm{kg}$ of RLV is generated monthly, which totals around 30 tons / year, processed in 3 (three) lapping machines on the State.

On mentioned region the disposal of the waste material follows a route that begins with the collection and temporary storage at the place of origin, being periodically removed through buckets with a 2-3 $\mathrm{m}^{3}$ of capacity, and finally led to an open pit deposit, sometimes mixed the larger grains. During the visit to the warehouse, information was obtained on the rejection of the material by the glass industry, including those portions mistakenly mixed with the coarse material during storage.

In order to avoid improperly disposing of non-recyclable waste, studies have been conducted with glass waste, mainly as a substitute for the binder (given its low particle size and chemical properties of pozzolanic material), and taking advantage of the grains above $75 \mu \mathrm{m}$ as fine aggregate, because the material behaves in this grain diameter [4]; Fine aggregate can also aid in compaction by filling voids between larger grains, but its application as a coarse aggregate is not indicated [5].

The use of these tailings has two advantages - it can reduce cement consumption and direct cost of mortar [6] - also considering the possibility of decreasing natural aggregate consumption.

It is noteworthy that the reduction of Portland cement meets the claims of environmentally friendly development, since cement production accounts for $5 \%$ of all $\mathrm{CO}_{2}$ produced worldwide, and consumes a large amount of energy in its production [7].

In addition to binder economy, fine glass powder also contributes to the ultimate strength as it has cementing properties of a pozzolanic material [8]. The strength gain tends to increase as the material becomes thinner [5].

Considering that the optimization of granulometry can change the packing density favoring the reduction of voids [9], it was decided to verify, in this study, the degree of packing (compaction) provided by the addition of fine glass dust in a certain range size of the selected sand.
The packing density is literally defined as "the fraction h of a volume filled by a given collection of solids" [10].

Londero [9] explains that packing density is essential for determining a suitable aggregate application with reduced void rates and optimized cement consumption in composites; and this (packing density) is directly related to the various particle size classes, possibly found in a given sand.

However, a particle size distribution, based on reduced grain diameters, can cause inconveniences related to the increase of the specific surface and, consequently, high water demand in the mixture or difficulties in workability [11]. Given the possibility of impairment of workability, the increase of water / cement ratio (a / c), to correct this fact, tends to impact mechanical performance ([6]; [12]), being the viable alternative the use of polyfunctional additive.

The fine glass powder in the cementitious mixture has recognized properties related to the pozzolanicity of the material; that is, it favors increased strength and durability of the composite material ([13]; [14]). But, chemically, it should be a matter of attention, since alkali-silica reactions tend to compromise cement hydration in combination with RLV, and given the presence of $\mathrm{Na}_{2} \mathrm{O}$ oxides in the composition, may generate material expandability reactions [15] .

Also is very important the shape of the beans. This factor may influence workability and consistency as lamellar and slightly rounded grains become less fluid [16]. However, heterogeneity in grain shape may have benefits in mechanical adhesion between aggregates and the cementitious matrix, increasing their bonding strength [17].

The study of the appropriate particle size range should contribute to the compaction of the composite, ie preferably composed of fine aggregates. In this sense, O. Ribeiro [18] selected about $90 \%$ of RLV with diameters smaller than $101.2 \mu \mathrm{m}$ in his research. Thus, the grain diameter can be easily defined, as the grinding process can be performed by various equipment e.g. ball mills, manual pylons and also using standard sieves, in the desired dimensions [3]. On the other hand, Arnold [19], in tests with mortars with $10 \%$ increase in filer content, found the smaller the material size, the more air incorporated, already in the fresh state. This material behavior means that need to optimize flowability and workability, as well as the search for an ideal $\mathrm{w} / \mathrm{c}$ ratio, factors that can lead to better results, already in the mixing process [12].

Regarding mechanical performance, in Turgut [4] tests on blocks made of glass dust, around $25 \mathrm{MPa}$ compressive strength was obtained in the composite, although in that study there was addition of fly ash and a type of powder from limestone crushers, to achieve better results. In another research, Aliabdo [20] tested $25 \%$ glass dust mortar, achieving $24 \mathrm{MPa}$ compressive strength within 7 days of cure; Simões [13] had better results with a maximum of $15 \%$ of addition, at about $31 \mathrm{MPa}$, at 28 days; and Islam [21], for $25 \%$ of waste at 28 days, reached about $30 \mathrm{MPa}$.

Aiming to determine the overall performance, this work studied some physical, chemical (compound identification) and mechanical characteristics of the fine glass lapping residues added to the cementitious mortar, replacing part of the natural fine aggregate in order to reduce the porosity and hypothetically improve compaction. This hypothesis was directly reflected in the mechanical performance, which was also evaluated. 


\section{Materials and experimental program}

\subsection{Materials characterization}

\subsubsection{Portland cement}

The chosen CP IV-32 has wide regional availability, produced by Votorantim Cimentos - Porto Velho. Tests were performed to determine the fineness modulus by sieving through $75 \mu \mathrm{m}$ mesh sieve [22] and the setting times were determined using the Vicat device [23]. Chemical characterization was performed by X-ray fluorescence, and its contents were identified for later comparison with the chemical composition of the RLV.

\subsubsection{RLV}

Lapidation residues were collected from the ETE (Effluent treatment plant), in an amount of approximately $50 \mathrm{~kg}$, in a pasty state, placed at rest in the shade for 20 days, where they

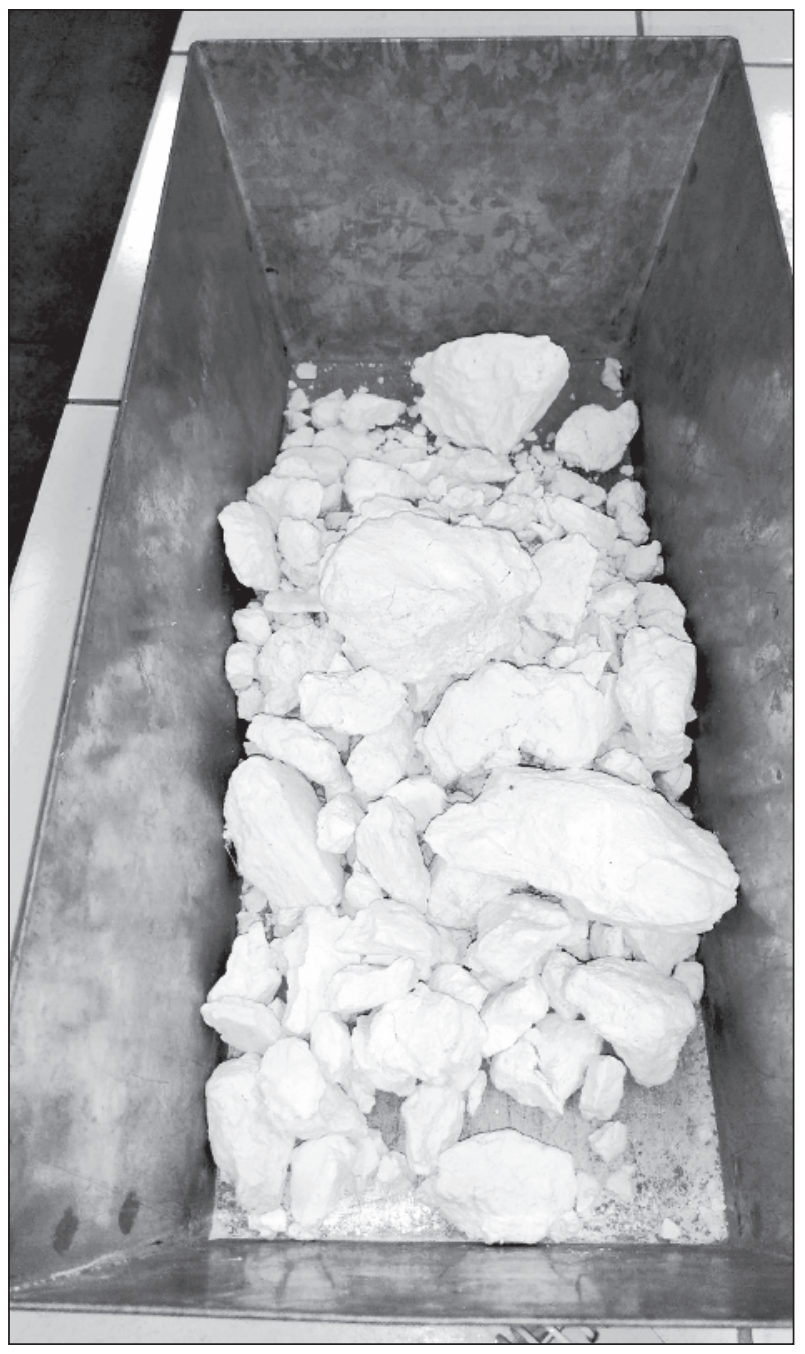

Figure 1

RLV air-dried after 20 days of collection acquired solid consistency by drying at room temperature; later reduced to clods (Figure 1 ).

To characterize the fineness of the RLV, once torn and ground through a grain mill, the procedure described in NBR 9289 [24] wash sieving was performed using $75 \mu \mathrm{m}$ (No. 200) and 300 mesh screens. $\mu \mathrm{m}$ (\# 50). The same procedure was used for hydrated lime fineness, since, after milling, RLV has similar fineness (since there is no specific standardization for its residue fineness). The sample to obtain the fineness index was $50 \mathrm{~g}$ through the $600 \mu$ mesh. The fraction of the powder selected for use was that passed through the $300 \mu \mathrm{m}$ mesh sieve.

In order to interpret the suitability between waste and sand grains, it was convenient to observe, by optical microscopy increased by $400 x$, the final shape of the grains to be used, after grinding and screening, whose image is presented and discussed below, In this job.

The specific mass of these residues was obtained by the Le Chatelier flask method using the common kerosene (NBR NM 23, [25]) as the immersion liquid.

Chemical analysis and loss on ignition of the RLV were requested from the Federal University of Paraná (UFPR), on a sample $(200 \mathrm{~g})$ of the material, ground and passing through the $300 \mu \mathrm{m}$ mesh sieve, fraction to be applied in the studies. These analyzes aimed to determine whether RLV aggregates chemical components incompatible with hydration and cement chemistry or with strength gain for the composite. The assays were developed by X-ray fluorescence using PANalytical Axios Max Spectrometer.

\subsubsection{Sand}

The sand (natural fine aggregate) used was extracted from the Candeias River in the municipality of Candeias do Jamary, RO (23 $\mathrm{km}$ from Porto Velho), collected directly from the extraction site ( $8^{\circ}$ $47^{\prime} 53.5^{\prime \prime} \mathrm{S} 63^{\circ} 42^{\prime} 47.3^{\prime \prime} \mathrm{W}$ ), aiming to obtain sand as clean as possible. Approximately $50 \mathrm{~kg}$ of the small aggregate were collected in piles stored at the site, taking care to bag samples from at least two distinct piles, aiming at a better representation of the material. The properties of sieving particle size analysis (NBR NM 248, [26]) and specific mass were obtained through the Chapman flask method (NBR 9776, [27]).

Aiming at a possible application of the composite material in coatings, replacing the conventional mortar, the particle size range (NBR 7211, [28]) of the passing conventional aggregate in the sieve $2.36 \mathrm{~mm}$ was used for the mixture. This fraction may contribute to better compaction combined with the thin diameter of the RLV. Matos [8] analyzed application with considerable demand of thinner aggregates $(\cong 2.36 \mathrm{~mm})$ in contribution to improve performance of self-compacting concretes.

\subsection{Experimental program}

\subsubsection{Dosage study and composite production}

Table 1 gives the definition of the tested mixtures with parts of the respective raw materials. To the production of specimens, standard procedures were used, following the $\mathrm{w} / \mathrm{c}$ ratio of 0.48 and the $1: 3$ dash (NBR 7215, [29]). 
Table 1

Definition of the ratios for the composites production, with contents related to cement mass

\begin{tabular}{ccc}
\hline Mixture & $\begin{array}{c}\text { Ratio cement: } \\
\text { [sand:RLV] + a/c + additive }\end{array}$ & Description \\
\hline RLV0 & $1:[3: 0]+0.48+0.008$ & Referência \\
RLV5 & $1:[2.85: 0.15]+0.48+0.008$ & $5 \%$ resíduo \\
RLV10 & $1:[2.70: 0.30]+0.48+0.008$ & $10 \%$ resíduo \\
RLV20 & $1:[2.40: 0.60]+0.48+0.008$ & $20 \%$ resíduo \\
\hline
\end{tabular}

For the binder, the aggregate parts (identified in Table 1 with "[ ]") were related, in order to $0 \%$ of RLV in the reference mixture (RLV0), reaching $20 \%$ of the residue for the largest amount by mass (RLV20) partially replacing the fine aggregate mass. Note that the sum of the aggregate parts for all mixtures retains the mass defined in the reference mixture. The percentage limits for waste mixtures follow other work already done ([4]; [12]; [20]). In an initial experimental mix, due to the unavailability of equipment for the flow table test [30], it was found that there was a high demand for water by the aggregates, which was noticeable in the kneading process, causing difficulties in workability. Thus, arbitrated plasticizer additive content of $0.8 \%$ of the cement mass was adopted (limit of $1 \%$ recommended by the manufacturer). MasterPolyheed $\circledast 30$ additive was chosen, used in the production of machined concretes and mortars. This additive has a chemical base in lignosulfonates (improves cohesion and decreases segregation), and density between 1.15 and $1.19\left(\mathrm{~g} / \mathrm{cm}^{3}\right)$ [31].

Packing density and bulk density were obtained using a $25 \mathrm{~cm}^{3}$ cylindrical container and tested one by one for sand, RLV and mixtures RLV5, RLV10 and RLV20; the bulk density obtained by method A (compacted) described in NBR NM 45 [32] and the packing density by Equation 1, for each material and for the mixtures, according to the percentage participation of the phases $(0,5,10$ and $20 \%$ ), being partial $\beta_{[[]}$summed to define $\beta_{\text {total }}$ of each mixture [33], according to Equation 2.

$\beta=1-\left[\frac{\gamma-\rho}{\gamma}\right]$

$\beta_{\text {total }}=\beta_{\text {sand }[i]}+\beta_{R L V[i]}$

Where,

$\beta$ is packing density;

$\gamma$ is specific mass;

$\rho$ is bulk density;

[i] is percentage contribution of each phase in the composite.

To determine the physical and mechanical properties of the composite, cylindrical specimens $50 \times 100 \mathrm{~mm}$ (diameter $\mathrm{x}$ height) were produced. The mixtures were prepared in a mechanical mortar mixer, with the cement unit fraction defined at $1500 \mathrm{~g}$ (Table 2), suf-

\section{Table 2}

Dosage, by mass, of the components of the mixtures (g)

\begin{tabular}{ccccc}
\hline Mixture & RLV0 & RLV5 & RLV10 & RLV20 \\
\hline Cement & 1500 & 1500 & 1500 & 1500 \\
RLV & 0 & 225 & 450 & 900 \\
Sand & 4500 & 4275 & 4050 & 3600 \\
Water & 720 & 720 & 720 & 720 \\
Plasticizer & 12 & 12 & 12 & 12 \\
\hline
\end{tabular}

ficient to mold, with each mixture, 10 cylindrical specimens, making a total of 40 specimens. RLV0 and RLV20. If there was excess material after the molding of each series, it was discarded.

Once molded the specimens, after $24 \mathrm{~h}$ were demoulded and immediately cured in a water immersion tank, remaining immersed for 25 days, after which non-destructive physical analyzes were performed before the destructive tests.

\subsubsection{Physical analysis of hardened composite}

The procedures for physical characterization were performed following the prescription in NBR 9778 [34]. For the tests, the specimens, in number of three specimens for each mixture, were initially oven-dried for $24 \mathrm{~h}$ at a temperature of $110 \pm 5^{\circ} \mathrm{C}$. The method used was the mass determinations by immersion in water (hydrostatic weighing); initially with dry weighing, then water saturation for $24 \mathrm{~h}$ (immersion), water immersed weighing and dry surface saturated weighing, recording the masses at each weighing.

\subsubsection{Mechanical analysis of hardened composite}

Mechanical performance tests were performed to determine the influence of RLV on the compressive strength of conventional material. The $50 \times 100 \mathrm{~mm}$ cylindrical specimens were submitted to axial compression, with 10 tests for each type of mixture. The compressive strength tests were performed at the age of 28 days of cure, at the Votorantim Cimentos Physical Testing Laboratory - Porto Velho. The specimens were prepared as prescribed in NBR 5738 [35]. The machine used was a Toni Technik, with load capacity up to 300 $\mathrm{kN}$, configured for load application at a constant speed of $0.25 \mathrm{Mpa} / \mathrm{s}$.

\section{Results and discussions}

\subsection{Material properties}

The Portland CP IV-32 cement used in this study showed a chemical composition with the percentage levels presented in Table 3,

\section{Table 3}

Chemical compositions of CP IV-32 and RLV

\begin{tabular}{ccccccccc}
\hline Material & $\mathrm{MgO}$ & $\mathrm{Al}_{2} \mathrm{O}_{3}$ & $\mathrm{SiO}_{2}$ & $\mathrm{SO}_{3}$ & $\mathrm{CaO}$ & $\mathrm{Fe}_{2} \mathrm{O}_{3}$ & $\mathrm{Na}_{2} \mathrm{O}$ & $\begin{array}{c}\text { Loss on } \\
\text { ignition }\end{array}$ \\
\hline CP IV $-32(\%)$ & 1.59 & 11.35 & 35.63 & 4.60 & 40.50 & 3.40 & - & - \\
RLV (\%) & 2.50 & 0.80 & 67.00 & 0.30 & 10.00 & 0.50 & 10.80 & 7.74 \\
\hline
\end{tabular}




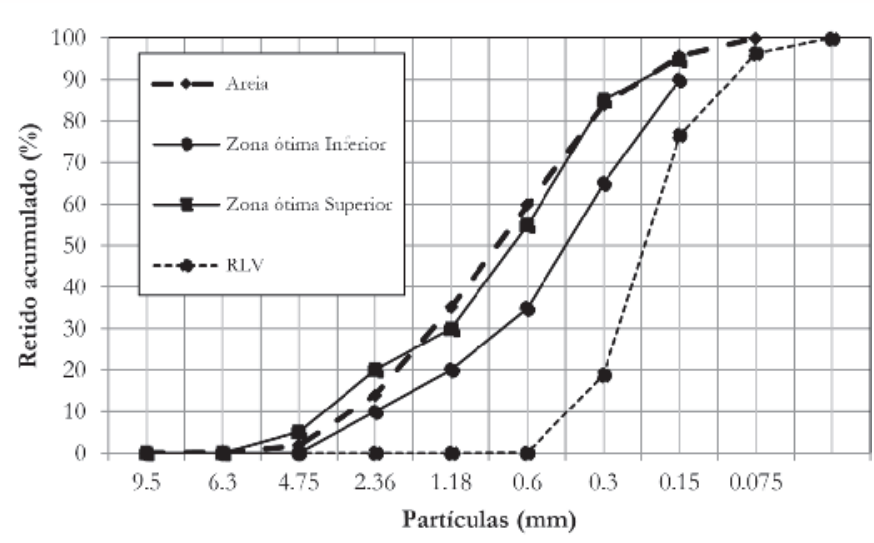

Figure 2

Fine aggregate and RLV particle size curve

compatible with the specifications of NBR 5736 [36], together with the results of the chemical analysis of the RLV, for comparison purposes.

The silicoaluminous components $\left(\mathrm{Al}_{2} \mathrm{O}_{3}+\mathrm{SiO}_{2}\right)$, characteristic of the pozzolanic material, contribute about $47 \%$ in the cement composition, not exceeding the specified normative values between $15-50 \%$ [36]. As the addition of RLV increases the silica content in the mixture (Table 3), pozzolanicity may be increased [13]. Al-

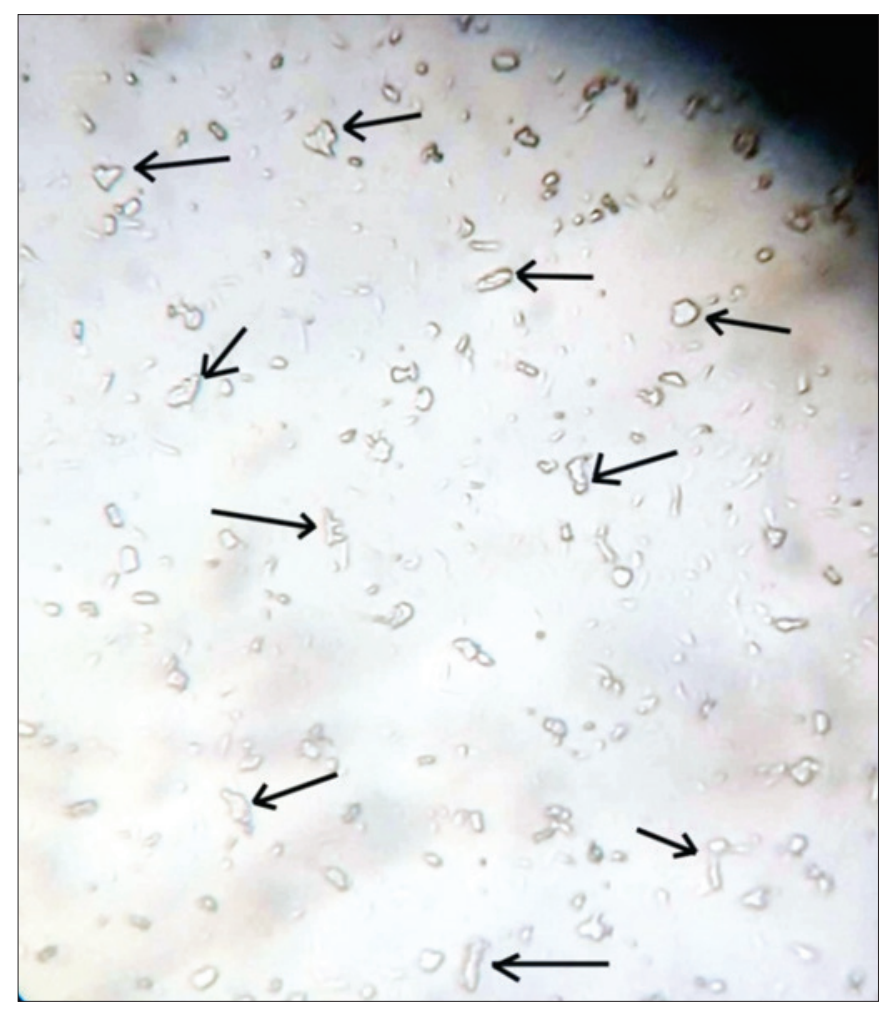

\section{Figure 3}

Shape of $300 \mu \mathrm{m}$ RLV grains, observed by optical microscopy, increased by 400x. Observe the angular, lamellar or elongated grains shape kali-silica reactions can generate material expandability due to the presence of sodium [15].

When compared to other pozzolanic material standard [37], RLV reached $68.3 \%$ for the total $\mathrm{SiO}_{2}+\mathrm{Al}_{2} \mathrm{O}_{3}+\mathrm{Fe}_{2} \mathrm{O}_{3}$ compounds, compared to the $50 \%$ required for pozzolanic material (for pozolanic $\mathrm{E}$ standard materials). However, other studies showed samples exceeding $70 \%$ for the compounds [4]. The loss on ignition, verified at $7.74 \%$, slightly exceeded the established in the standard, which is $6 \%$ maximum.

The result of the sand particle size analysis resulted in a regular curve (Figure 2), showing to be an aggregate of well distributed grain diameters, being in a fineness modulus range 2.90 , almost totally in the standardized optimum zone (NBR 7211 , [28]).

Residual grains (Figure 3 ) were often lamellar or angular. As the grain shape could not be controlled in the milling process, this may have potentiated the workability (as already mentioned in the dosage study), since the grain shape influences the consistency [16] and the friction between them can cause difficulties in the mixing process. However, heterogeneity in grain shape may have benefits in mechanical adhesiveness [17].

Irregular grain geometry is not just the case with larger grains. Also with $33 \mu \mathrm{m}$ microparticles, observed by Scanning Electron Microscopy, this feature has already been proven [3].

The sample of residues with passing grains in the $600 \mu \mathrm{m}$ sieve mesh, submitted to the washing fineness procedure [24], showed that $56.55 \%$ are smaller than $300 \mu \mathrm{m}$. Already by dry sieving (NBR NM 248, [26]) - Figure 2, this index rises to close to $80 \%$. Other research reports up to $90 \%$ of RLV with grains below 101.2 [18]. Considering the same grain range $(<600 \mu \mathrm{m})$ for the natural fine aggregate, it was observed that only $16 \%$ are less than $300 \mu \mathrm{m}$. This shows that the RLV below $600 \mu \mathrm{m}$ has a higher powdery grain mass than sand. Therefore, there is a possibility of achieving better compression ratios. Regarding the fineness of the analyzed cement, it was verified in $6.7 \%$, being below $8 \%$, the maximum standardized for this type of cement [36], also showing that more than $93 \%$ of the grains have a diameter smaller than or equal to $75 \mu \mathrm{m}$, indicating better suitability of compaction and pozzolanic reaction with the RLV grains used.

The waste grains $(<=300 \mu \mathrm{m})$ will fill in the voids between the sand grains in the $2.36 \mathrm{~mm}$ range. Since the specific mass of conventional sand is higher than that of RLV (Table 4), this indicates that the substitution by the residue will not increase the specific mass of the hardened composite. Thus, the higher the percentage of substitution, the smaller will be the specific mass of the dry state composite.

\subsection{Hardened composites}

In evaluations of moisture and porosity absorption levels, the RLV0 (reference) presented index between 1.5 and $2 \%$, respectively,

\section{Table 4}

Specific mass of materials

\begin{tabular}{ccc}
\hline Materials & $\left(\mathbf{g} / \mathbf{c m}^{3}\right)$ & Method \\
\hline RLV & $2.34 \pm 0.01$ & NBR NM 23 [25] \\
Sand & $2.65 \pm 0.01$ & NBR 9776 [27] \\
CP IV - 32 & $2.97 \pm 0.03$ & NBR NM 23 [25] \\
\hline
\end{tabular}




\section{Table 5}

Physical characteristics of hardened composites determined by immersion in water. $\mathrm{CV}=$ coefficient of variation

\begin{tabular}{|c|c|c|c|c|c|c|c|c|}
\hline \multirow{2}{*}{$\begin{array}{l}\text { Composite } \\
\text { Index }\end{array}$} & \multicolumn{2}{|l|}{ RLVO } & \multicolumn{2}{|c|}{ RLV5 } & \multicolumn{2}{|c|}{ RLV10 } & \multicolumn{2}{|c|}{ RLV20 } \\
\hline & Average & $\mathrm{cV}$ & Average & $\mathrm{cv}$ & Average & $c v$ & Average & cV \\
\hline $\begin{array}{c}\text { Moisture absorption } \\
(\%)\end{array}$ & $5.63 \pm 0.23$ & 4.16 & $4.43 \pm 0.32$ & 7.31 & $6.09 \pm 0.96$ & 15.80 & $5.96 \pm 0.64$ & 10.72 \\
\hline $\begin{array}{l}\text { Voids index } \\
(\%)\end{array}$ & $11.75 \pm 0.46$ & 3.94 & $9.31 \pm 0.64$ & 6.89 & $12.33 \pm 1.82$ & 14.77 & $11.73 \pm 1.18$ & 10.03 \\
\hline $\begin{array}{l}\text { Specific mass } \\
\left(\mathrm{g} / \mathrm{cm}^{3}\right)\end{array}$ & $2.09 \pm 0.01$ & 0.46 & $2.10 \pm 0.01$ & 0.43 & $2.03 \pm 0.02$ & 1.17 & $1.97 \pm 0.02$ & 0.77 \\
\hline
\end{tabular}

higher than the RLV5. Although the difference between the averages is not high, the coefficients of variation practically double in value, e.g., $7.31 \%$ (RLV5) against $4.16 \%$ (RLV0), for moisture absorption. (Table 5). The high relative variation in porosity and moisture absorption index may indicate the occurrence of material segregation during composite preparation. Mean void indexes indicate a decrease in RLV5, with a tendency towards stabilization in RLV20, with index close to the RLV0 composite. In this item the fineness of the material may influence the incorporation of voids [19], already in the fresh state. This fact, combined with the possible segregation of the materials, may determine the increase in the voids index as the fine residue content increases. The increase in voids does not affect specific mass significantly until RLV10 (Table 5), and the differences only for RLV20 are better noticeable. Even though no significant reduction in specific mass was found, for the dry sample there was a significant decrease between the

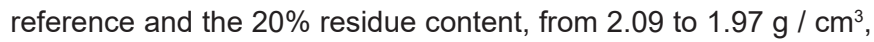
approximately $6 \%$.

\subsection{Mechanical performance and cement consumption}

The analysis of variance (ANOVA) performed on compressive strength results, for each residue content, indicated a difference at $5 \%$ significance level. Analyzing the averages (Table 6 ) by pairs (Tukey test), it was found that all treatments have significant difference in relation to the reference composite (RLV0), but none among them (RLV5 to RLV20). The differences between RLV0 and RLV5, RLV10 and RLV20 were $36.2 \%, 20.8 \%$ and $23.4 \%$, respectively, with more than $27 \mathrm{MPa}$ average for the latter. In Turgut tests [4] it was approximately $25 \mathrm{MPa}$.

The $5 \%$ residue showed a better fit between RLV and sand fines. For other percentages, there is a decrease in strength, possibly caused by failures in densification / mixing and / or segregation of materials, due to impaired workability; Even so, at $20 \%$ addition, the composite was 1.23 times stronger than the reference. The

\section{Table 6}

Results of the compressive strength tests

\begin{tabular}{cccc}
\hline \multicolumn{4}{c}{ Compressive strength (MPa) } \\
\hline RLV0 & RLV5 & RLV10 & RLV20 \\
\hline $22,18 \pm 3,2 \mathrm{a}$ & $30,21 \pm 2,0 \mathrm{~b}$ & $26,79 \pm 4,5 \mathrm{~b}$ & $27,36 \pm 2,5 \mathrm{~b}$ \\
\hline
\end{tabular}

Note: Averages with different letters indicate significant difference between them by the Tukey test at $5 \%$ probability

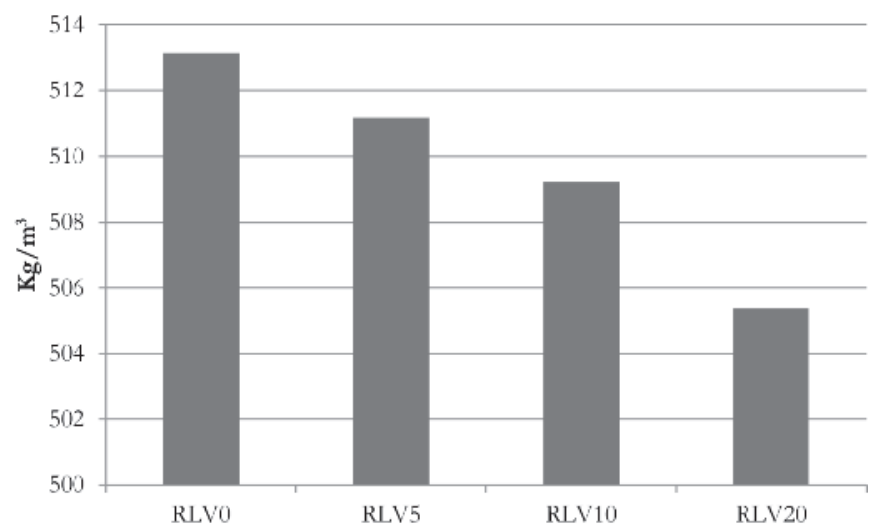

Figure 4

Cement consumption

increase in compressive strength in general is largely due to the cementing properties of the thin glass residue. On the other hand, a factor that would imply loss of resistance is the increase in the voids index (Table 5), as the residues increase.

Despite the reduction in workability, maintaining the water / cement ratio at 0.48 contributed greatly to compressive strength. Miranda Jr. [12], with an increase of this index (reaching 0.58), showed a decrease in resistance to about $17 \mathrm{MPa}$ at 28 days, for any residue levels tested $(0-20 \%)$. In this sense, the literature shows that better results for the addition of glass powder to the cementitious mortar occurred with substitutions around $25 \%$. Aliabdo [20] reached 24 $\mathrm{MPa}$ within 7 days of healing; Simões [13] obtained about $31 \mathrm{MPa}$ at 28 days; and Islam [21] at 28 days reached about $30 \mathrm{MPa}$.

In this work it was verified a cement consumption (Figure 4) reduced by $1.54 \%$ between RLV0 and RLV20, even without reducing the binder mass in the mixtures. This can be explained by the higher particle packing density (Table 7), which tends to reduce the spaces to be filled by the cement paste [11]; Moreover, since the

\section{Table 7}

Characteristics of the footings

\begin{tabular}{ccc}
\hline Material & Bulk density & $\beta$ \\
\hline Sand & $1.614 \pm 0.022$ & 0.61 \\
RLV0 & $1.058 \pm 0.057$ & 0.45 \\
RLV5 & $1.697 \pm 0.009$ & 0.64 \\
RLV10 & $1.738 \pm 0.009$ & 0.66 \\
RLV20 & $1.758 \pm 0.022$ & 0.68 \\
\hline
\end{tabular}


specific mass of the waste is smaller than sand, substitution with the same mass tends to increase the volume of solids [16], reducing the cement consumption per $\mathrm{m}^{3}$. The RLV20 composite has the advantage of lower cement consumption and mechanical strength gain of over $23 \%$, as well as lower density among all composites. The packing density is naturally higher for sand grains, given their bulk density greater than RLV [9]. On the other hand, when analyzing the mixtures, the packing densities increase as the fine material content increases. The value of $\beta=0.64$ for RLV5 already demonstrates an improvement in grain compaction, increasing to RLV20, i.e there is better grain suitability in mixtures than in conventional material.

\section{Conclusions}

This work aimed to analyze some physical, chemical and mechanical properties of the conventional material and glass lapping residues, as well as a hardened cementitious composite (mortar).

The chemical analysis of cement and RLV showed a optimization in pozzolanicity, due to the increase in the content of $\mathrm{SiO}_{2}+\mathrm{Al}_{2} \mathrm{O}_{3}+$ $\mathrm{Fe}_{2} \mathrm{O}_{3}$ compounds, with improvement of the cementing properties. Due to the bonding properties of RLV, the compressive strength for the RLV5 composite reached $30.2 \mathrm{MPa}$ at 28 days, representing the best performance, about $36 \%$ above reference. The other contents of additions also showed higher resistance than conventional, although lower than RLV5.

The increase in fine aggregate content led to increased water consumption and difficulties in workability, low grain size effect and irregular shape (lamellar and angular) of the waste grains. The low workability may have generated waste segregation, which justifies an increase in voids above RLV5. Thus, the best suitability for compaction is the addition of low residue for passing sand grains in the $2.36 \mathrm{~mm}$ mesh.

On the other hand, the higher residue content $(20 \%)$ caused the specific mass reduction of the composite by $6 \%$ for RLV20. Also in this mixture there was a small reduction in cement consumption, by $1.54 \%$, due to better particle packing and increased volume of solids, reducing the cement paste.

The study suggests optimizing the water / cement ratio to improve workability, avoid material segregation and reduce voids, as well as to test other particle size ranges of the conventional aggregate, with a view to adjusting the packing relationed to the RLV.

\section{Acknowledgments}

The authors thank the Faculty of Rondônia - FARO, for assigning the Concrete Laboratory for Experiments and Votorantim Cement - Porto Velho, for conducting mechanical tests.

\section{References}

[1] Brasil, Presidência da República. LEI No 12.305, DE 2 DE AGOSTO DE 2010. Institui a Política Nacional de Resíduos Sólidos; altera a Lei no 9.605 , de 12 de fevereiro de 1998; e dá outras providências, (2010). Disponível em: < http://www.planalto.gov.br/ccivil_03/_Ato2007-2010/2010/ Lei/L12305.htm> Acesso em: outubro de 2018.
Vargas, Isabella M., Wiebeck, Hélio. Reciclagem de Vidro Laminado: Utilização dos Vidros de Baixa Granulometria como Carga Abrasiva na Formulação de Vernizes de Alto Tráfego para Pisos de Madeira. Polímeros: Ciência e Tecnologia, vol. 17, n² 2, p. 137-144, (2007).

[3] Galvão, A. C. P.; Farias, A. C. M.; Mendes, J. U. L.. Characterization of waste of soda-lime glass generated from lapping process to reuse as filler in composite materials as thermal insulation. Cerâmica, São Paulo, v. 61, n. 359, p. 367-373, Sept. 2015 . Disponível em: < http:// www.scielo.br/scielo.php?script=sci_arttext\&pid=S0366$69132015000300367 \&$ Ing=en\&nrm=iso >. accesso em 20 out. 2018. http://dx.doi.org/10.1590/036669132015613591987.

[4] Turgut, Paki. Fly Ash Block Containing Limestone and Glass Powder Wastes. KSCE Journal of Civil Engineering, 17(6):1425-1431, (2013).

[5] Antônio, A. P., Potencialidades do aproveitamento do resíduo de estação de tratamento de efluentes do processo de lapidação de vidro sodo-cálcico na produção de concretos. Dissertação (mestrado em engenharia civil) - Universidade Federal do Espírito Santo, Centro Tecnológico (2012). Disponível em: < http://repositorio.ufes. br/handle/10/3949> Acesso: setembro de 2018.

[6] Braga, M., Brito, J. de, Veiga, R. Reduction of the cement content in mortars made with fine Concrete aggregates. Materials and Structures 47:171-182 (2014) DOI 10.1617/s11527-013-0053-1. Disponível em: < https://www.researchgate.net/profile/Maria_Veiga2/publication/257895991_Reduction_of_the_cement_content_in_mortars_made_with_fine_concrete_aggregates/ links/54fa45e10cf23e66f03128b9/Reduction-of-the-cement-content-in-mortars-made-with-fine-concrete-aggregates.pdf > Acesso em: 20/10/2018.

[7] Krizova, K., Hela, R., Use of Green cement in concrete for friendly building construction. In: Latest Trends in Sustainable and Green Development, pp. 17-21, Barcelona, Spain, oct. (2012).

[8] Matos, A. M., Ramos, T., Nunes, S., Sousa-Coutinho, J., Durability Enhancement Of SCC With Waste Glass Powder. Materials Research, 19(1): 67-74, (2016).

[9] Londero, C., L. A. Lenz, dos Santos, Í. M. R., Klein, N. $\mathrm{S}$. Determination of the particle packing of granular systems composed with the Brazilian standard sand from IPT: comparison between models for particle size distribution optimization and random compositions. Cerâmica, São Paulo, v. 63, n. 365, p. 22-33, Mar. 2017 . Disponível em: < http://www.scielo.br/scielo.php?script=sci arttext\&pid=S0366-69132017000100022\&Ing=en\&nr m=iso $>$. acesso em 22 outubro 2018. http://dx.doi. org/10.1590/0366-69132017633652018.

[10] Weisstein, Eric W. „Packing Density.“ From MathWorld--A Wolfram Web Resource. Disponível em/: < http://mathworld.wolfram.com/PackingDensity.html > acesso em: 27/10/2018.

[11] Mehdipour, Iman, and Kamal H. Khayat. "Effect of particle-size distribution and specific surface area of different 
binder systems on packing density and flow characteristics of cement paste." Cement and Concrete Composites 78:120-131, (2017).

Miranda Jr., E. J. P., Bezerra, H. J. C. L., Politi, C. S., Paiva, A. E. M., Increasing the Compressive Strength of Portland Cement Concrete Using Flat Glass Powder. Materials Research, 17(Suppl. 1): 45-50, (2014).

[13] Simões, L. J., Estudo da aplicação de resíduo de vidro laminado na produção de concreto. Dissertação (Mestrado em Engenharia Civil) Universidade Federal do Espírito Santo, (2013). Disponível em: < http://repositorio. ufes.br/jspui/bitstream/10/3968/1/tese_7343_Lorena\%20 Jodoni\%20Sim\%C3\%B5es.pdf - 24/06/2017 > Acesso: outubro de 2017

[14] Palhares, R. A., Pereira, A. R. S., Cabral, K. C., Nobrega, A. K. C. Avaliação da Atividade Pozolânica dos Resíduos de Cerâmica Vermelha Produzidos no Vale do Assú/Rn. In: $22^{\circ} \mathrm{CBECiMat}$ - Congresso Brasileiro de Engenharia e Ciência dos Materiais, Natal, Brasil, (2016).

[15] V. Ribeiro, D., Silva, A. M. S., Labrincha, J. A., Morelli, M. $R$. Estudo das reações alcalis-sílica associadas ao uso da lama vermelha em argamassas colantes e de revestimento. Cerâmica. 58: 90-98, (2012).

[16] Weidmann, D. F. Contribuição ao Estudo da Influência da Forma e da Composição Granulométrica de Agregados Miúdos de Britagem nas Propriedades do Concreto de Cimento Portland. Dissertação (Mestrado em Engenharia Civil) Universidade Federal de Santa Catarina, Florianópolis, (2008). Disponível em: < https://repositorio. ufsc.br/handle/123456789/106626 > Acesso: outubro de 2018.

[17] Martins, L. B. S., Produção de Rocha Artificial Utilizando Resíduo de Etapa de Laminação de Vidro Plano em Matriz de Resina Polimérica. Dissertação (Mestrado em Engenharia e Ciência dos Materiais) Universidade Estadual do Norte Fluminense, Campos dos Goytacazes, (2016). Disponível em: < http://uenf.br/posgraduacao/engenharia-de-materiais/wp-content/uploads/sites/2/2013/07/ DISSERTA\%C3\%87\%C3\%830-COMPLETA-Lucas-Martins-final.pdf > Acesso: junho de 2017.

[18] O. Ribeiro, A. Estudo de resíduo da lapidação de vidro para incorporação em argamassa de cimento Portland. Dissertação (mestrado) - Universidade Federal de Uberlândia, Programa de Pós-graduação em Engenharia Civil. Uberlândia, MG, Brasil (2015).

[19] Arnold, D. C. M., Kazmierczak, C. S. Influência da Distribuição Granulométrica do Agregado Miúdo e do Teor de Fíler nas Propriedades de Argamassas com Areia de Britagem. Universidade do Vale do Rio dos Sinos, Programa de Pós-graduação em Engenharia Civil. (2009) Disponível em: < http://www.dcc.ufpr.br/mediawiki/images/8/82/TC034_Marienne_Artigo_Granulometria.pdf > Acesso: outubro de 2018

[20] Aliabdo A. A., Elmoaty A. E. M. A., Aboshama, A. Y., Utilization of waste glass powder in the production of cement and concrete. Construction and Buildings Materials, 124: 866-877, (2016).
[21] Islam, G. M. S., Rahman, M. H., Kazi, N. Waste glass powder as partial replacement of cement for sustainable concrete practice. International Journal of Sustainable Built Environment, $\mathrm{n}^{\circ}$ 6, p. 37-44, (2017).

[22] ABNT - Associação Brasileira de Normas Técnicas. NBR 11579: Cimento Portland - Determinação do índice de finura por meio da peneira $75 \mu \mathrm{m}\left(n^{\circ} 200\right)$. Rio de Janeiro ABNT, 4p. (2012).

[23] ABNT - Associação Brasileira de Normas Técnicas. NBR NM 65: Cimento portland - Determinação do tempo de pega. Rio de Janeiro ABNT, 4p. (2003).

[24] ABNT - Associação Brasileira de Normas Técnicas. NBR 9289: Cal hidratada para argamassas - determinação da finura. Rio de Janeiro ABNT, 4p. (1998).

[25] ABNT - Associação Brasileira de Normas Técnicas. NBR NM 23: Cimento portland e outros materiais em pó - Determinação da massa específica. Rio de Janeiro ABNT, 5p. (2001).

[26] ABNT - Associação Brasileira de Normas Técnicas. NBR NM 248: Agregados - Determinação da composição granulométrica. Rio de Janeiro: ABNT, 8p. (2003).

[27] ABNT - Associação Brasileira de Normas Técnicas. NBR 9776: Agregados - Determinação da massa específica de agregados miúdos por meio do frasco Chapman. Rio de Janeiro ABNT, 3p. (1988).

[28] ABNT - Associação Brasileira de Normas Técnicas. NBR 7211: Agregados para concreto - Especificação. Rio de Janeiro ABNT,. 9p. (2009).

[29] ABNT - ASSOCIAÇÃO BRASILEIRA DE NORMAS TÉCNICAS. NBR 7215: Cimento Portland - Determinação da resistência à compressão. Rio de Janeiro: ABNT, 1996. 8p.

[30] ABNT - ASSOCIAÇÃO BRASILEIRA DE NORMAS TÉCNICAS. NBR 12276:2002: Argamassa para assentamento e revestimento de paredes e tetos - Preparo da mistura e determinação do índice de consistência. Rio de Janeiro ABNT, 3p. (2002).

[31] BASF SA. Linha MasterPolyheed®: Aditivo plastificante polifuncional - Ficha Técnica. Disponível em: <https:// assets.master-builders-solutions.basf.com/Shared\%20 Documents/PDF/Portuguese\%20(Brazil)/Ficha_Tecnica_ MasterPolyheed.pdf.> Acesso em julho de 2017.

[32] ABNT - ASSOCIAÇÃO BRASILEIRA DE NORMAS TÉCNICAS. NBR NM 45: Agregados - Determinação da massa unitária e do volume de vazios. Rio de Janeiro: ABNT, 2006. 8p.

[33] Raj, Narasimha, Patil, Suresh G., Bhattacharjee, B. Concrete Mix Design By Packing Density Method. IOSR Journal of Mechanical and Civil Engineering (IOSR-JMCE). V. 11, Issue 2, p. 34-46, Ver. I (Mar- Apr. 2014), (2014). Disponível em: < http://www.iosrjournals.org/iosr-jmce/ papers/vol11-issue2/Version-1/F011213446.pdf > acesso em: 02/11/2018.

[34] ABNT - ASSOCIAÇÃO BRASILEIRA DE NORMAS TÉCNICAS. NBR 9778: Argamassas e concretos endurecidos - Determinação da absorção de água, índice de vazios e massa específica. Rio de Janeiro ABNT, 4p. (2006). 
[35] ABNT - Associação Brasileira de Normas Técnicas. NBR 5738: Concreto - Procedimento para moldagem e cura de corpos-de-prova. Rio de Janeiro ABNT, 6p. (2003).

[36] ABNT - ASSOCIAÇÃO BRASILEIRA DE NORMAS TÉCNICAS. NBR 5736: Cimento Portland Pozolânico. Rio de Janeiro ABNT, 5p. (1991).

[37] ABNT - Associação Brasileira de Normas Técnicas. NBR 12653: Materiais Pozolânicos - Requisitos. Rio de Janeiro ABNT, 5p. (2012). 